\title{
Reducing Egypt Rock Phosphate Use in Zea mays Cultivation on an Acid Soil Using Clinoptilolite Zeolite
}

\author{
Hasbullah Nur Aainaa ${ }^{1}$, Osumanu Haruna Ahmed ${ }^{1,2,3}$, Susilawati Kasim ${ }^{1} \&$ Nik Muhamad Ab. Majid ${ }^{2}$ \\ ${ }^{1}$ Department of Crop Science, Faculty of Agriculture and Food Sciences, Universiti Putra Malaysia Bintulu \\ Campus, 97008 Bintulu, Sarawak, Malaysia \\ ${ }^{2}$ Institute of Tropical Forestry and Forest Products (INTROP), Universiti Putra Malaysia, 43400 Serdang, \\ Selangor, Malaysia \\ ${ }^{3}$ Agriculture and Environment, Borneo Eco-Science Research Center, Faculty of Agriculture and Food Sciences, \\ Universiti Putra Malaysia Bintulu Campus, 97008 Bintulu, Sarawak, Malaysia
}

Correspondence: Osumanu Haruna Ahmed, Department of Crop Science, Faculty of Agriculture and Food Sciences, Universiti Putra Malaysia Bintulu Campus, 97008 Bintulu, Sarawak, Malaysia. E-mail: osman60@hotmail.com; osumanu@upm.edu.my

Received: June 10, 2014 Accepted: November 7, 2014 Online Published: December 4, 2014

doi:10.5539/sar.v4n1p56 URL: http://dx.doi.org/10.5539/sar.v4n1p56

\begin{abstract}
Insufficient supply of $\mathrm{P}$ for initial growth of crops does not only limit $\mathrm{N}$ uptake but it also leads to poor yield of crops. In acidic soils of the tropics, sorption of $\mathrm{P}$ occurs mainly on surfaces of $\mathrm{Fe}$ and $\mathrm{Al}$ oxides and hydroxides. Most of the $\mathrm{P}$ added through mineral fertilizers is fixed by high $\mathrm{Al}$ and $\mathrm{Fe}$ oxide concentrations and transformed into insoluble $\mathrm{P}$ compounds. Reduction of $\mathrm{Al}$ and $\mathrm{Fe}$ is important so as to ensure adequate supply and readily available $\mathrm{P}$ for crops uptake. A number of studies using zeolites as an amendment in the fertilization programs of crops have improved crops production, nutrients uptake, and nutrients use efficiency. However, there is dearth of information on the use of clinoptilolite zeolite $(\mathrm{CZ})$ to reduce $\mathrm{P}$ fixation not to mention reduction of $\mathrm{N}, \mathrm{P}$, and $\mathrm{K}$ fertilizers use in agriculture. This study was conducted to: (i) determine dry matter production, nutrients concentration, nutrients uptake, and use efficiency of Zea mays (Hibrimas variety) by including CZ in the fertilization program of Zea mays planted on an acidic soil, and (ii) determine the effect of including $\mathrm{CZ}$ in the fertilization program of Zea mays on selected chemical properties of an acidic soil. Egypt rock phosphate (ERP), urea, and muriate of potash were used in this study. Seventy five percent $(w / w)$ of the recommended N, P, and K fertilizers for Zea mays were combined with CZ. Standard procedures were used to determine soil $\mathrm{pH}$, inorganic nitrogen, available phosphorus, exchangeable aluminium, iron, potassium, calcium, magnesium, and organic matter before and after planting. Zea mays were harvested at tasselling stage and measured for dry matter production, nutrients uptake and use efficiency. The effect of $\mathrm{CZ}$ application with $75 \%$ of fertilizers (E2) and $100 \%$ fertilizers (E1) were statistically similar for selected soil chemical properties, dry matter production, nutrients concentration, uptake of nutrients, and nutrients use efficiency except for N. Nitrogen use efficiency for $\mathrm{E} 2$ was better than that of E1. These findings suggest that adoption of $\mathrm{CZ}$ with $25 \%$ reduction of $\mathrm{N}, \mathrm{P}$, and $\mathrm{K}$ fertilizers are useful. Further field trials and economic analysis are recommended to confirm the findings of this study. These aspects are being investigated in our on-going field experiments.
\end{abstract}

Keywords: zeolites, acid soils, nutrient use efficiency, fertilizers management, rock phosphate

\section{Introduction}

Phosphorus plays an important role in plant metabolism and it is one of the essential nutrients required for plant growth and development. Its deficiency in soils does not only limit $\mathrm{N}$ uptake but it also leads to poor yield of crops. In acidic soil of the tropics, dominance of metal hydroxides such as $\mathrm{Al}$ and $\mathrm{Fe}$ are responsible for $\mathrm{P}$ sorption. Application of $\mathrm{P}$ from the mineral phosphate results in $\mathrm{P}$ sorption through physical adsorption or chemical precipitation with dissolved $\mathrm{Fe}, \mathrm{Al}$, and $\mathrm{Mn}$ ions to form insoluble hydroxyl-phosphate precipitates (Sims \& Pierzynski, 2005; Kochian et al., 2004; Brady et al., 2004; Fontes et al., 1996). Due to high P fixation and immobilization in acidic soils, high amount of $\mathrm{P}$ fertilizer is applied to saturate the capacity of acidic soils for $\mathrm{P}$ sorption and to ensure $\mathrm{P}$ availability for plant uptake. Excessive use of $\mathrm{P}$ fertilizers will become a greater threat as cumulative accumulation of available P in soils may enter water bodies through soil erosion (Zhou \& Zhu, 
2003) rather than leaching (Ruban, 1999). Besides, prolong use of $P$ fertilizers may cause environmental pollution such as eutrophication. Therefore, effective management of $\mathrm{P}$ fertilizers will not only increase crops yield but it will also reduce costs of production, and conservation of finite resources.

Zeolites are natural aluminosilicates with an infinite three-dimensional crystal structure, a polyedric shape, with a great open cavity (Ajirloo et al., 2013; Ramesh et al., 2011; Daković et al., 2007). These abundant and cheap minerals are used in agriculture as soil conditioners, slow-release fertilizers, and agents for contaminated soil (Ming \& Allen, 2001). Zeolites remain in the soil to improve retention of nutrients and they are not easily degraded over time (Ramesh et al., 2010). Therefore, zeolite additions significantly reduce irrigation and fertilizer costs by retaining water and beneficial nutrients in the root zone (Polat et al., 2004). The micro-porous structures of zeolites lead to high water adsorption and retention of nutrients, control the release of plant nutrient, free soluble nutrients that exist in soils for plant use (Eberl, 1993; Zelazny et al., 1977). These functions suggest that zeolites improve soil fertility and water retention.

In Malaysia, the agricultural sector is the third contributor to the Malaysian economic growth. About $90 \%$ of chemical fertilizers is required to sustain the agricultural sector of Malaysia. The fertilizer import bills were USD $\$ 209$ million and USD\$ 319 million in 2009 and 2013, respectively (ITC calculations based on UN COMTRADE statistics) and the price is estimated to increase yearly. Instead of using soluble P fertilizers such as Triple superphosphate, the use of rock phosphates is preferable because they are cheaper and their dissolution is favourable in acidic condition (Akande et al., 2008; Nnadi \& Haque, 1998). Phosphorus release through the use of zeolites and rock phosphate (RP) were demonstrated by exchange-induced dissolution system (Allen et al., 1993).

$$
\mathrm{RP} \text { (rock phosphate) }+\mathrm{NH}_{4}^{+}+\text {zeolite } \rightleftarrows \text { Ca- zeolite }+\mathrm{NH}_{4}{ }^{+}+\mathrm{H}_{2} \mathrm{PO}_{4}{ }^{-}
$$

Clinoptilolite zeolite is used to retain $\mathrm{NH}_{4}^{+}$or $\mathrm{K}^{+}$because the cations selectivity of zeolites is in the order of $\mathrm{Cs}^{+}>$ $\mathrm{Rb}^{+}>\mathrm{K}^{+}>\mathrm{NH}_{4}^{+}>\mathrm{Ba}^{2+}>\mathrm{Sr}>\mathrm{Na}^{+}>\mathrm{Ca}^{2+}>\mathrm{Fe}^{3+}>\mathrm{Al}^{3+}>\mathrm{Mg}^{2+}>\mathrm{Li}^{+}$(Mumpton, 1999). Plant uptake of cations from clinoptilolite zeolite leads to vacant exchange sites which $\mathrm{Ca}^{2+}$ are attracted to. This process lowers the activity of $\mathrm{Ca}^{2+}$ from soil solution thereby inducing dissolution of rock phosphate (RP) and also producing ammonium ions as by-product (Pickering et al., 2002; Allen et al., 1995; Barbarick et al., 1993; Lai \& Eberl, 1986). Dissolution of RP is also partly attributed to rhizosphere acidification (Zhang et al., 2004). Although zeolites have been used to improve plant nutrients uptake and use efficiency, there is dearth of information on the use of zeolites to reduce $\mathrm{P}$ sorption in soil not to mention reduction of $\mathrm{N}, \mathrm{P}$, and $\mathrm{K}$ fertilizers use in agriculture. Thus, this study was carried out to: (i) determine dry matter production, nutrients concentration, uptake, and use efficiency of Zea mays by including clinoptilolite zeolite in the fertilization program of Zea mays planted on an acidic soil, and (ii) determine the effect of including clinoptilolite zeolite in the fertilization program of Zea mays on selected chemical properties of an acidic soil.

\section{Materials and Methods}

The clinoptilolite zeolite used in this study was imported from Indonesia. The mineral soil of Typic Paledults (Bekenu series) used in this study was sampled from an uncultivated area of Universiti Putra Malaysia Bintulu Sarawak Campus, Malaysia using a shovel. The soil sample was taken at $0-15 \mathrm{~cm}$ depth, air dried, and ground to pass a $5.0 \mathrm{~mm}$ sieve for pot study and $2.0 \mathrm{~mm}$ for laboratory analysis.

The soil used was analyzed before and after the pot study. Soil texture was determined using the hydrometer method (Tan, 2005). $\mathrm{pH}$ of the soil and clinoptilolite zeolite were determined in a 1:25 ratio (soil: distilled water) using a digital $\mathrm{pH}$ meter (Peech, 1965). Soil organic matter was determined using the loss-on-ignition method (Piccolo, 1996); bulk density by the method described by Tan (2005). Soil total P (extracted using aqua regia) and available P (extracted using double acid method) (Tan, 2005) were determined using UV-spectrometer after blue color development (Murphy \& Riley, 1962). Soil cation exchange capacity (CEC) was determined using the ammonium acetate method (Cottenie, 1980). However, the CEC of the Clinoptilolite zeolite was determined using the $\mathrm{CsCl}$ method (Ming \& Dixon, 1986). The $\mathrm{CsCl}$ method used avoids underestimation of CEC of the zeolites as the method does not lead to entrapment of ammonium ions in its channels. Exchangeable cations ( $\mathrm{K}$, $\mathrm{Ca}, \mathrm{Mg}$, and $\mathrm{Fe}$ ) were also extracted using the ammonium acetate method and their concentrations were determined using atomic absorption spectrometry (PerkinElmer AAnalyst 800). Total soil acidity is the sum of $\mathrm{H}^{+}$and $\mathrm{Al}^{3+}$ and were extracted using $1 \mathrm{M} \mathrm{KCl}(1: 10$ soil/solution) and determined using colorimetric method (Rowell, 1994). Soil total N was extracted using the Kjedahl method (Bremner, 1965) whereas inorganic nitrogen (available $\mathrm{NO}_{3}{ }^{-}$and exchangeable $\mathrm{NH}_{4}{ }^{+}$) was determined using the method described by Keeney and Nelson (1982). 
The pot study was conducted at Universiti Putra Malaysia Bintulu Sarawak Campus, Malaysia. The experimental design was completely randomized with four replicates. An $8 \mathrm{~kg}$ of soil was used per pot based on the soil's bulk density and pot size of $25 \mathrm{~cm}$ (top diameter) $\times 21 \mathrm{~cm}$ (bottom diameter) $\times 21 \mathrm{~cm}$ (height). Maize (Zea mays L.) Hibrimas (commonly used in Malaysia) was used as test crop. The recommended rates of N, P, and $\mathrm{K}$ fertilizers used were $60 \mathrm{~kg} \mathrm{~N} \mathrm{ha}^{-1}, 60 \mathrm{~kg} \mathrm{P}^{-1}$, and $40 \mathrm{~kg} \mathrm{~K} \mathrm{ha}^{-1}$ (Malaysian Agricultural Research and Development Institute, 1990). The recommended rates of the fertilizers used in this study were scaled down to per plant basis equivalent [Urea (4.85 $\left.\mathrm{g} \mathrm{plant}^{-1}\right)$, Egyptian Rock Phosphate (ERP) (7.95 $\left.\mathrm{g} \mathrm{plant}^{-1}\right)$ and Muriate of Potash (MOP) $\left.\left(2.47 \mathrm{~g} \mathrm{plant}^{-1}\right)\right]$ from the standard fertilizer recommendation (Malaysian Agricultural Research and Development Institute, 1990). Treatments evaluated were as follows:

(1) No fertilizer (T0)

(2) $4.85 \mathrm{~g}$ urea $+2.47 \mathrm{~g}$ muriate of potash $+7.95 \mathrm{~g}$ Egypt rock phosphate (E1)

(3) $3.64 \mathrm{~g}$ urea $+1.85 \mathrm{~g}$ muriate of potash $+5.96 \mathrm{~g}$ Egypt rock phosphate $+12.75 \mathrm{~g}$ zeolite (E2)

The treatments consisted of without fertilizer (T0), application of $100 \%$ recommended fertilizers (E1), and $75 \%$ recommended fertilizers plus clinoptilolite zeolite (E2). The quantity of the CZ used in this study was derived from a ratio of [2.5:3] $\mathrm{CZ}$ to $100 \%$ fertilizers $(\mathrm{w} / \mathrm{w})$.

A day before planting, $\mathrm{CZ}$ was mixed thoroughly with soil before the mixture was filled in the pot. The volume of water for each pot was based on $60 \%$ of field capacity (Five seeds were sown and thinned to one at seven days after sowing). The muriate of potash $\left(60 \% \mathrm{~K}_{2} \mathrm{O}\right)$, and Egypt rock phosphate $\left(28 \% \mathrm{P}_{2} \mathrm{O}_{5}\right)$, and urea $(46 \% \mathrm{~N})$ were surface applied and afterwhich they were covered with soil (to avoid for example loss of urea through ammonia volatilization). Unlike $\mathrm{CZ}$ which applied once in the beginning of the pot study, split applications of the fertilizers (amount of treatment applied as mention above divided by half at each time of application) were carried out on $10^{\text {th }}$ and $28^{\text {th }}$ days after seeding (DAS). Plants were harvested at 50 DAS (tasseling stage). Tasselling stage is the maximum growth stage of the plants before they go to reproductive stage (Susilawati et al., 2009).

A day before harvesting, soil samples were taken using a mini auger. Afterwards, the soil was air dried, ground, and sieved to pass $2 \mathrm{~mm}$ and analyzed for physico-chemical properties using standard procedures as described previously. Plant leaves and stems were harvested at 50 days after seeding. The remaining roots in the soil were removed carefully and cleaned using tap and distilled water. The plant parts (leaves, stems, and roots) were then oven dried at $60^{\circ} \mathrm{C}$ until constant weight was attained afterwhich their dry matter were determined. Each plant part was ground and analyzed for tolal $\mathrm{N}$ using Kjedahl method (Bremmer, 1965) whereas the single dry ashing method (Cottenie, 1980) was used for the extraction of $\mathrm{P}$ and $\mathrm{K}$ in the plant tissues. The filtrates were analyzed using atomic absorption spectrometry (Perkin Elmer AAnalyst 800) for $\mathrm{K}$ whereas $\mathrm{P}$ was determined using UV-spectrometer. Nitrogen, P, and K uptake in leaves, stems, and roots were determined by multiplying their concentrations with the dry weight of the plant parts, whereas N, P, and K use efficiency (agronomic effectiveness) were determined using the formula shown below (Dobermann, 2005):

Nutrient Use Efficiency $(\%)=\frac{(A-B)}{C} \times 100$

Where $\mathrm{A}=$ uptake with fertilizer, $\mathrm{B}=$ uptake without fertilizer, $\mathrm{C}=$ total amount of fertilizer that had been applied; uptake of nutrient $=$ nutrient concentration $(\%) \times$ dry weight $(\mathrm{g})$.

Analysis of variance (ANOVA) was used to test significant effect of treatments whereas means of treatments were compared using Tukey test. Statistical Analysis System (SAS version 9.2) was used for the statistical analysis.

\section{Results and Discussion}

\subsection{Dry Matter Production, Nutrients Concentration, Nutrients Uptake, and Use Efficiency}

Plant dry matter production and nutrients concentration results are shown in Table 1. Application of CZ in the fertilization (E2) resulted in similar dry matter production as normal fertilization (E1). The poor dry matter production of plants in $\mathrm{T} 0$ was due to no fertilization to sustain plant growth and development.

Regardless of treatment, nutrient concentration in stem showed no significant effect. The treatment with CZ (E2) significantly increased $\mathrm{N}$ concentration in leaves compared with normal fertilization (E1) and no fertilization (T0). Unlike $\mathrm{N}$, concentrations $\mathrm{P}$ in leaves and roots of the unfertilized plants were significantly higher than those of the fertilized plants. This is because plants with low dry matter normally show higher nutrient 
concentration due to poor growth which is associated with poor nutrients translocation compared to healthy plants (Marschner, 1995).

The use of $\mathrm{CZ}$ with reduced amount of fertilizers (E2) as compared to those of E1 (100\% fertilization) showed similar N, P, and K uptake (Figures 1, 2, and 3). This finding suggests the need to reduce excessive use of fertilizers to minimize loss and environmental pollution. Phosphorus and $\mathrm{K}$ use efficiency in E2 was comparable to that of E1 (Figures 5 and 6). Nitrogen use efficiency of E2 (Figure 4) was however better than that of E1. Perhaps better retention of cations and their timely releases by clinoptilolite zeolite for the Zea mays utilization led to better $\mathrm{N}$ use efficiency in E2. Higher $\mathrm{N}$ efficiency is indeed important to reduce surface and ground water contamination (Ramesh et al., 2010).

Table 1. Dry matter production and nutrients concentration of Zea mays plants without fertilization (E0), recommended fertilization (E1), and 75\% fertilization with Clinoptilolite zeolite (E2) at 50 days after seeding

\begin{tabular}{lllll}
\hline Treatment & Dry matter (g) & \multicolumn{3}{c}{ Nutrient concentration (\%) } \\
& & $\mathbf{N}$ & $\mathbf{P}$ & $\mathbf{K}$ \\
\hline Leaves & & & & \\
T0 & $0.97 \mathrm{~b}$ & $0.50 \mathrm{c}$ & $0.27 \mathrm{a}$ & $3.25 \mathrm{a}$ \\
E1 & $10.62 \mathrm{a}$ & $1.09 \mathrm{~b}$ & $0.15 \mathrm{~b}$ & $2.88 \mathrm{ab}$ \\
E2 & $9.52 \mathrm{a}$ & $1.77 \mathrm{a}$ & $0.15 \mathrm{~b}$ & $2.79 \mathrm{~b}$ \\
Stem & & & & \\
T0 & $0.37 \mathrm{~b}$ & $0.41 \mathrm{a}$ & $0.19 \mathrm{a}$ & $3.87 \mathrm{a}$ \\
E1 & $8.93 \mathrm{a}$ & $1.08 \mathrm{a}$ & $0.16 \mathrm{a}$ & $4.59 \mathrm{a}$ \\
E2 & $7.55 \mathrm{a}$ & $0.97 \mathrm{a}$ & $0.17 \mathrm{a}$ & $4.64 \mathrm{a}$ \\
Root & & & $0.90 \mathrm{a}$ \\
T0 & $0.95 \mathrm{~b}$ & $0.35 \mathrm{a}$ & $0.14 \mathrm{a}$ & $1.17 \mathrm{a}$ \\
E1 & $15.43 \mathrm{a}$ & $0.81 \mathrm{a}$ & $0.08 \mathrm{~b}$ & $1.24 \mathrm{a}$ \\
E2 & $14.41 \mathrm{a}$ & $0.48 \mathrm{a}$ & $0.10 \mathrm{~b}$ & $8.03 \mathrm{a}$ \\
Total & & & & $8.64 \mathrm{a}$ \\
T0 & $2.29 \mathrm{~b}$ & $1.26 \mathrm{~b}$ & $0.61 \mathrm{a}$ & $8.67 \mathrm{a}$ \\
E1 & $34.99 \mathrm{a}$ & $2.98 \mathrm{a}$ & $0.39 \mathrm{~b}$ & $0.41 \mathrm{~b}$ \\
E2 & $31.49 \mathrm{a}$ & $3.22 \mathrm{a}$ & & \\
\hline
\end{tabular}

Note: Means within column with different letters indicate significant difference using Tukey test at $p \leq 0.05$.

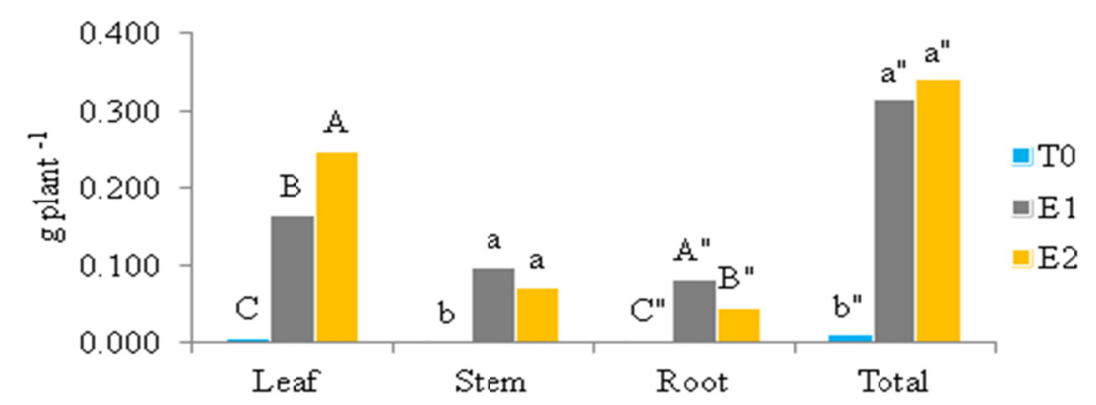

Figure 1. Nitrogen uptake of Zea mays plants without fertilization (E0), recommended fertilization (E1), and 75\% fertilization with clinoptilolite zeolite (E2) at 50 days after seeding. Means with different letter indicates significant differences using Turkey test $p \leq 0.05$ 


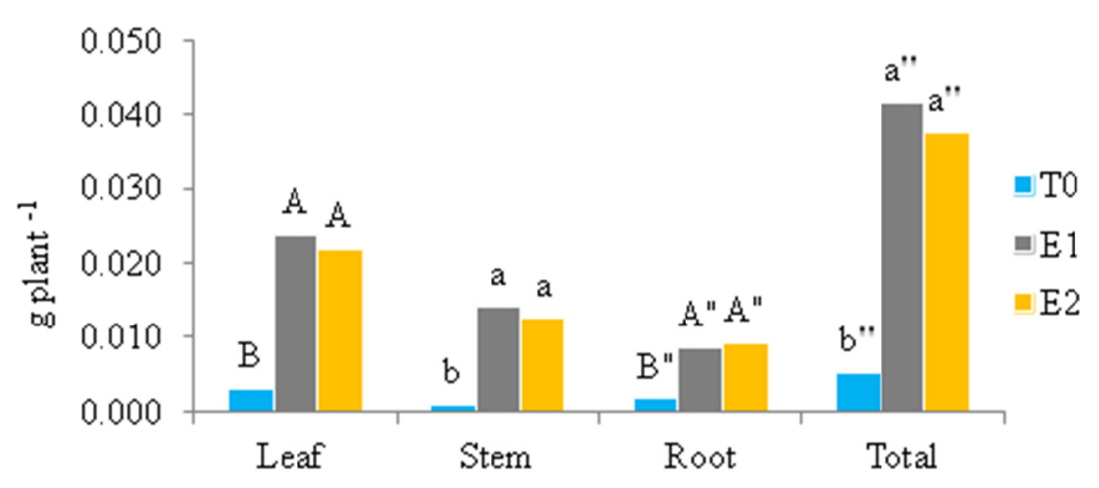

Figure 2. Phosphorus uptake of Zea mays plants without fertilization (E0), recommended fertilization (E1), and $75 \%$ fertilization with clinoptilolite zeolite (E2) at 50 days after seeding. Means with different letter indicates significant differences using Turkey test $p \leq 0.05$

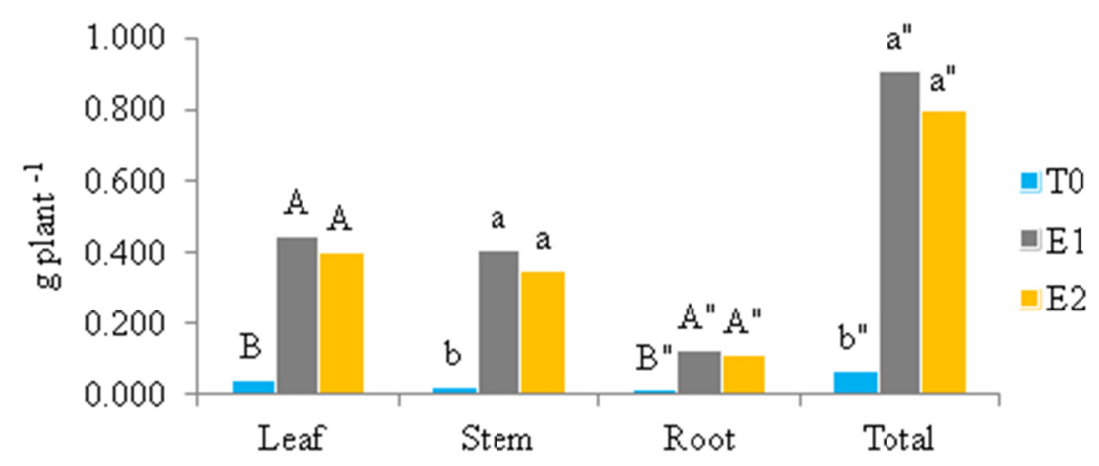

Figure 3. Potassium uptake of Zea mays plants without fertilization (E0), recommended fertilization (E1), and 75\% fertilization with clinoptilolite zeolite (E2) at 50 days after seeding. Means with different letter indicates significant differences using Turkey test $p \leq 0.05$

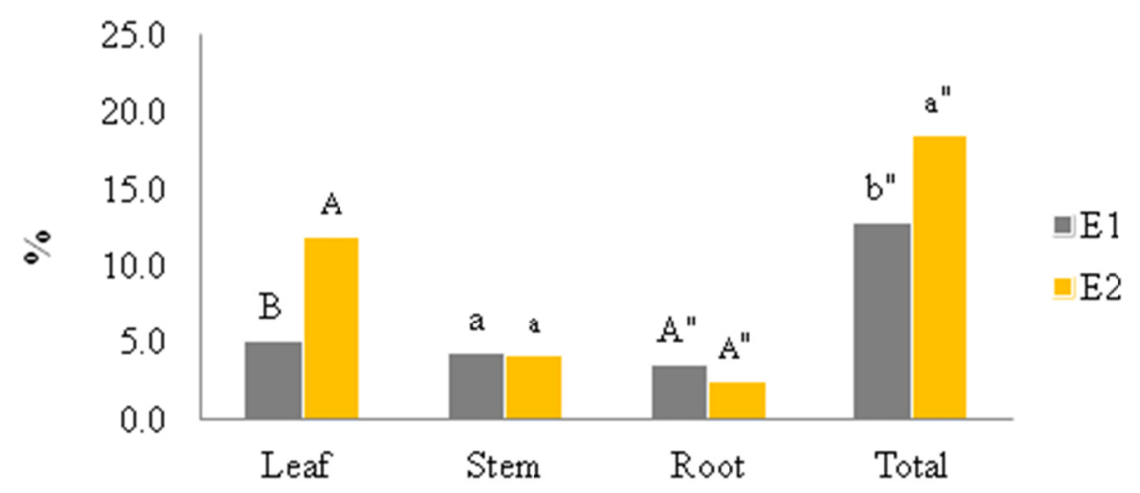

Figure 4. Nitrogen use efficiency of Zea mays plants without fertilization (E0), recommended fertilization (E1), and $75 \%$ fertilization with clinoptilolite zeolite (E2) at 50 days after seeding. Means with different letter indicates significant differences using Turkey test $p \leq 0.05$ 


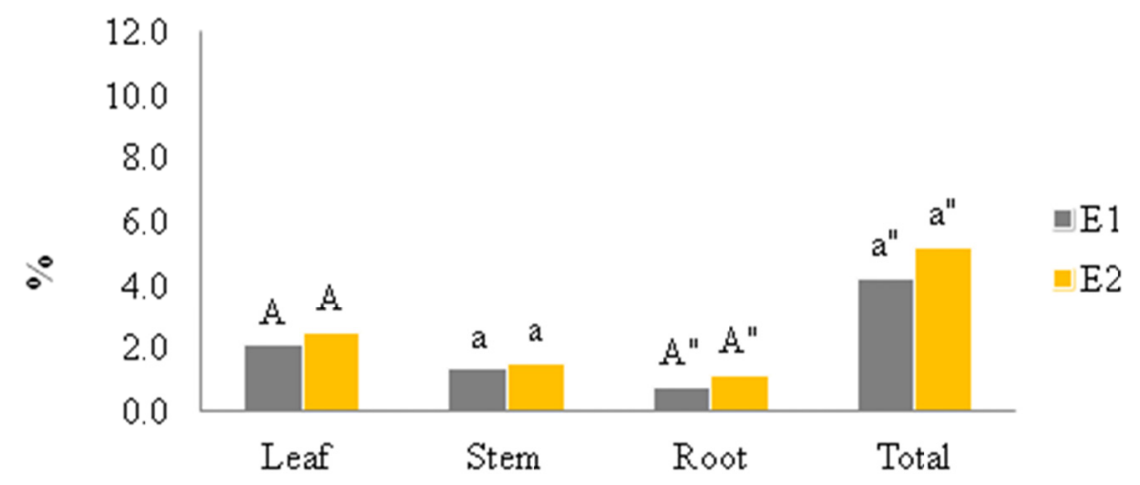

Figure 5. Phosphorus use efficiency of Zea mays plants without fertilization (E0), recommended fertilization (E1), and 75\% fertilization with clinoptilolite zeolite (E2) at 50 days after seeding. Means with different letter indicates significant differences using Turkey test $p \leq 0.05$

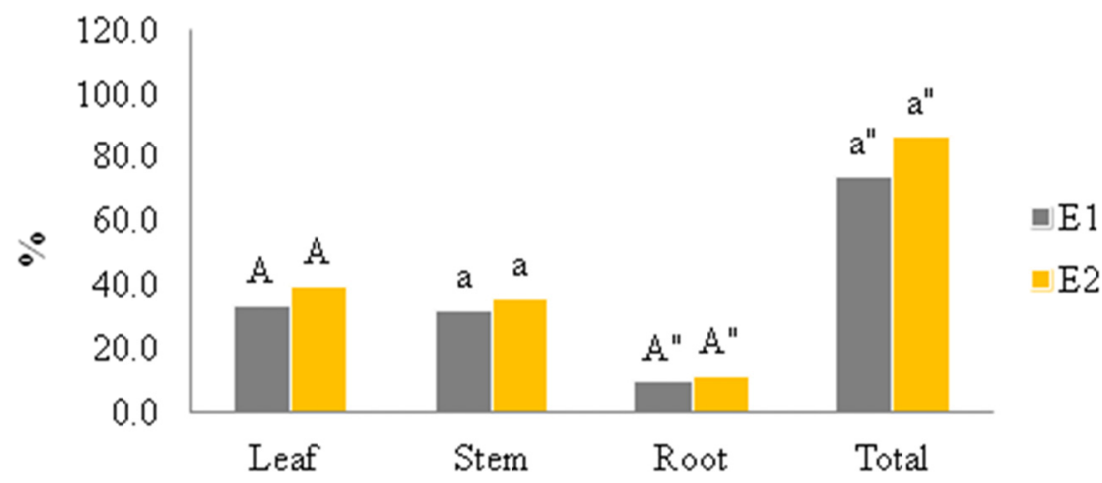

Figure 6. Potassium use efficiency of Zea mays plants without fertilization (E0), recommended fertilization (E1), and $75 \%$ fertilization with clinoptilolite zeolite (E2) at 50 days after seeding. Means with different letter indicates significant differences using Turkey test $p \leq 0.05$

\subsection{Effect of Treatments on Selected Soil Chemical Properties}

Table 2 shows selected soil chemical properties at 49 DAS. The effects of E0, E1 and E2 were not significantly different on soil $\mathrm{pH}, \mathrm{OM}$, exchangeable $\mathrm{Mg}$, and $\mathrm{NO}_{3}{ }^{-}$. Studies had shown that $\mathrm{CZ}$ promotes $\mathrm{N}$ retention in soils as it improves the use of ammonium and nitrate by reducing leaching losses of exchangeable cations (Polat et al., 2004; He et al., 2002). However, the lack of significant effect of $\mathrm{CZ}$ to retain $\mathrm{NH}_{4}^{+}$was likely due to competitive adsorption from $\mathrm{K}^{+}$. This is shown by similar $\mathrm{K}$ recorded in $\mathrm{E} 2$ compared to $100 \%$ fertilizer application. These observations corroborate those of Tarkalson and Ippolito (2011). Tarkalson and Ippolito (2011) reported significant dominance of $\mathrm{K}^{+}$over $\mathrm{NH}_{4}^{+}$at the exchange sites of $\mathrm{CZ}$. This is possible because $\mathrm{CZ}$ ion selectivity follows the order of $\mathrm{K}^{+}>\mathrm{NH}_{4}^{+}>\mathrm{Na}^{+}>\mathrm{Ca}^{2+}>\mathrm{Mg}^{2+}$, thus supporting the debate of cations competition at the exchange site of CZ (Rahmani et al., 2004). The significantly lower soil exchangeable Ca (Table 2) in E2 compared to E1 could attributed to PR dissolution which indirectly answers the comparable total P observation of E1 and E2.

Despite the similar total $\mathrm{P}$, the significant reduction in $\mathrm{P}$ availability contents in E1 and E2 of the soils suggests that considerable proportion of $\mathrm{P}$ was fixed and unavailable to plants (Figure 7). The reason for this may be that $\mathrm{Ca}$ from the zeolite reacted with $\mathrm{P}$ released from rock $\mathrm{P}$ to form insoluble $\mathrm{Ca}-\mathrm{P}$ complexes which is generally not available to plants (Petrus et al., 2010). Besides, part of the P released may have reacted with exchangeable Fe and Al to form insoluble complexes. This explains their significant reduction in the soil (Figure 8 and 9).

Soil exchangeable acidity significantly increased with fertilizer application (Figure 10). The acidification attributed to nitrification, root exudation, and active cations exchange activity of $\mathrm{CZ}$ cations with protons ions in soil solution (Ajirloo et al., 2013) explains the significant increase of $\mathrm{H}^{+}$ion in E1 and E2 as compared to soil 
alone. Significant reduction of total soil acidity in $\mathrm{E} 1$ and $\mathrm{E} 2$ is related to $\mathrm{Al}^{3+}$ complexes and precipitation with available $\mathrm{P}$ (Figure 11).

Table 2. Selected chemical properties of soil without fertilization (E0), recommended fertilization (E1), and 75\% fertilization with clinoptilolite zeolite (E2) at 49 days after seeding

\begin{tabular}{|c|c|c|c|c|c|c|c|}
\hline & \multirow{2}{*}{ pH } & \multirow{2}{*}{ OM (\%) } & \multicolumn{3}{|c|}{ Exchangeable Cation $\left(\mathrm{cmol} \mathrm{kg}^{-1}\right)$} & \multirow{2}{*}{ Exchangeable $\mathrm{NH}_{4}^{+}(\%)$} & \multirow{2}{*}{ Available $\mathrm{NO}_{3}^{-}(\%)$} \\
\hline & & & $\mathbf{K}$ & $\mathbf{C a}$ & Mg & & \\
\hline T0 & $5.31^{\mathrm{a}}$ & $5.75^{\mathrm{a}}$ & $0.10^{\mathrm{b}}$ & $0.53^{\mathrm{c}}$ & $0.41^{\mathrm{a}}$ & $0.009^{b}$ & $0.001^{\mathrm{a}}$ \\
\hline E1 & $5.49^{\mathrm{a}}$ & $6.00^{\mathrm{a}}$ & $0.53^{\mathrm{a}}$ & $1.91^{\mathrm{a}}$ & $0.46^{\mathrm{a}}$ & $0.018^{\mathrm{a}}$ & $0.002^{\mathrm{a}}$ \\
\hline E2 & $5.56^{\mathrm{a}}$ & $5.65^{\mathrm{a}}$ & $0.51^{\mathrm{a}}$ & $1.76^{\mathrm{b}}$ & $0.50^{\mathrm{a}}$ & $0.017^{\mathrm{ab}}$ & $0.003^{\mathrm{a}}$ \\
\hline
\end{tabular}

Note: Means within column with different letters indicate significant difference using Tukey test at $p \leq 0.05$.

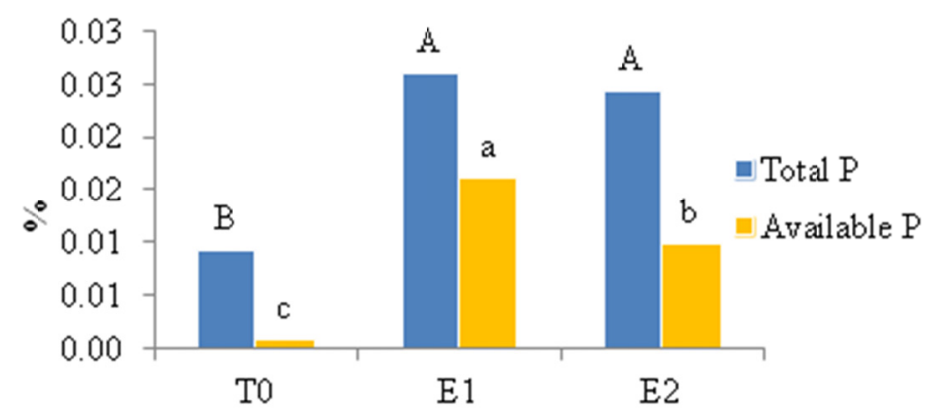

Figure 7. Total and available $\mathrm{P}$ of soils without fertilization (E0), recommended fertilization (E1), and 75\% fertilization with clinoptilolite zeolite (E2) at 49 days after seeding. Means with different letter indicates significant differences using Turkey test $p \leq 0.05$

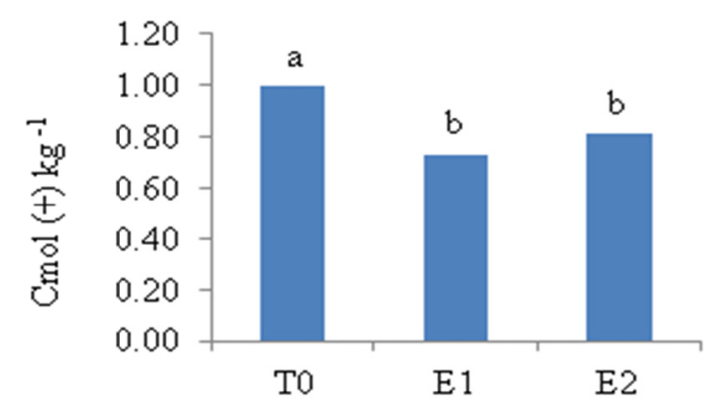

Figure 8. Exchangeable Fe of soils without fertilization (E0), recommended fertilization (E1), and $75 \%$ fertilization with clinoptilolite zeolite (E2) at 49 days after seeding. Means with different letter indicates significant differences using Turkey test $p \leq 0.05$ 


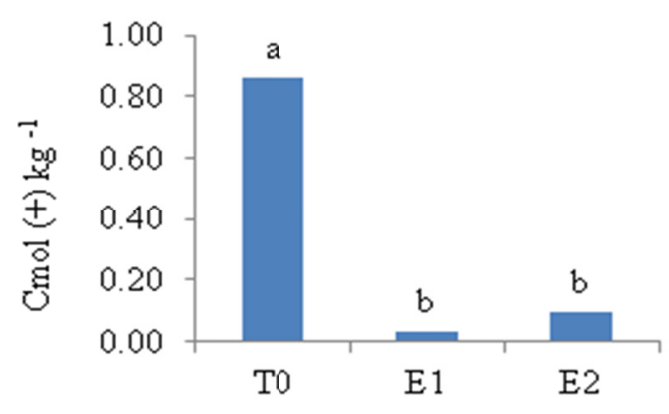

Figure 9. Exchangeable Al of soils without fertilization (E0), recommended fertilization (E1), and $75 \%$ fertilization with clinoptilolite zeolite (E2) at 49 days after seeding. Means with different letter indicates significant differences using Turkey test $p \leq 0.05$

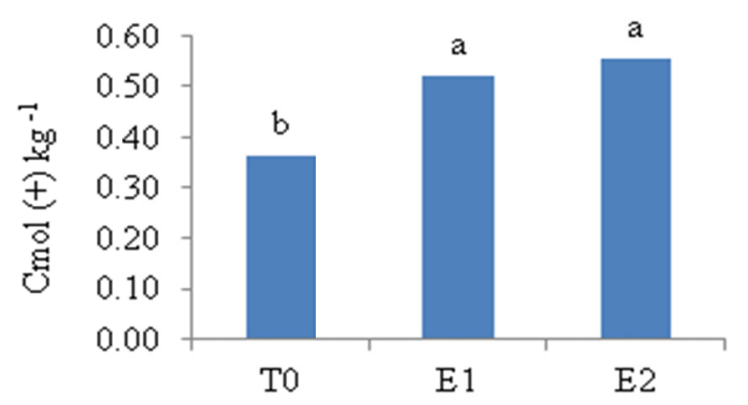

Figure 10. Exchangeable acidity of soils without fertilization (E0), recommended fertilization (E1), and 75\% fertilization with clinoptilolite zeolite (E2) at 49 days after seeding. Means with different letter indicates significant differences using Turkey test $p \leq 0.05$

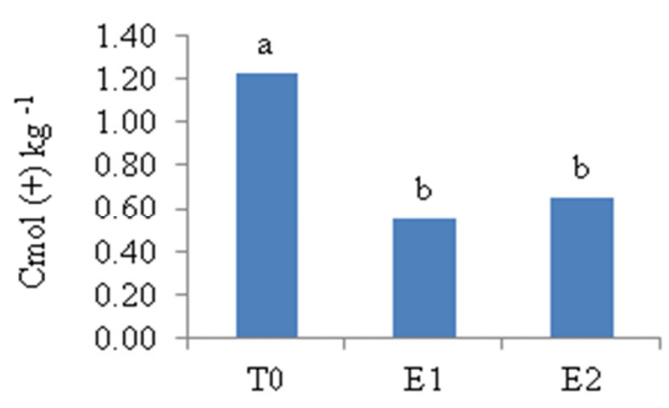

Figure 11. Total titrate-able acidity of soils without fertilization (E0), recommended fertilization (E1), and 75\% fertilization with $25 \%$ clinoptilolite zeolite (E2) at 49 days after seeding. Means with different letter indicates significant differences using Turkey test $p \leq 0.05$

Although in this study the effect of $\mathrm{CZ}$ was not obvious on the selected soil chemical properties, $\mathrm{CZ}$ application demonstrated $\mathrm{P}$ release through exchange-induced dissolution system. As phosphate is taken up by plants or by soil fixation, more phosphate and ammonium is released in the attempt to re-establish equilibrium as a result of a specific chemical reaction in the soil.

\subsection{Characterization of Soil, ERP and Clinoptilolite Zeolite}

The selected physico-chemical properties of Bekenu series, clinoptilolite zeolite, and Egypt rock phosphate are shown in Table 3. The soil was indeed acidic, as shown by a $\mathrm{pH}$ value of 4.32 . Furthermore, the soil had a low value of CEC, being $5.33 \mathrm{cmol}(+) \mathrm{kg}^{-1}$, and a low content of total $\mathrm{N}$, being $0.06 \%$. Total carbon, exchangeable $\mathrm{K}, \mathrm{Ca}$, and $\mathrm{Mg}$ were slightly higher than the standard range of this soil type (Paramananthan, 2000) and this 
could possibly be due to litter decomposition with time at the soil surface since the experimental soil was taken from an uncultivated area.

Table 3. Selected Chemical Properties of soil, clinoptilolite zeolite, and Egypt rock phosphate

\begin{tabular}{|c|c|c|c|c|}
\hline Property & $\begin{array}{l}\text { Soil } \\
\text { Value obtained }\end{array}$ & $\begin{array}{l}\text { Standard } \\
\text { data range* }\end{array}$ & Clinoptilolite Zeolite & Egypt Rock Phosphate \\
\hline pH (water) & 4.32 & $4.6-4.9$ & 8.54 & $\mathrm{Nd}$ \\
\hline Bulk Density $\left(\mathrm{g} \mathrm{cm}^{-3}\right)$ & 1.01 & $\mathrm{Nd}$ & $\mathrm{Nd}$ & $\mathrm{Nd}$ \\
\hline CEC $\left(\mathrm{cmol} \mathrm{kg}^{-1}\right)$ & 5.33 & $3.86-8.46$ & 75.4 & $\mathrm{Nd}$ \\
\hline Total N (\%) & 0.06 & $0.04-0.17$ & $\mathrm{Nd}$ & $\mathrm{Nd}$ \\
\hline Total P (\%) & 0.005 & $\mathrm{Nd}$ & $\mathrm{Nd}$ & 11.96 \\
\hline Available $P\left(\mathrm{mg} \mathrm{kg}^{-1}\right)$ & 2.48 & $\mathrm{Nd}$ & $\mathrm{Nd}$ & $\mathrm{Nd}$ \\
\hline Organic Matter (\%) & 5.6 & $\mathrm{Nd}$ & $\mathrm{Nd}$ & $\mathrm{Nd}$ \\
\hline Organic Carbon (\%) & 3.25 & $0.57-2.51$ & $\mathrm{Nd}$ & $\mathrm{Nd}$ \\
\hline $\begin{array}{l}\text { Exchangeable Al } \\
\left(\mathrm{cmol} \mathrm{kg}^{-1}\right)\end{array}$ & 0.9 & $\mathrm{Nd}$ & $\mathrm{Nd}$ & $\mathrm{Nd}$ \\
\hline $\begin{array}{l}\text { Exchangeable } \mathrm{H} \\
\left(\mathrm{cmol} \mathrm{kg}^{-1}\right)\end{array}$ & 0.48 & $\mathrm{Nd}$ & $\mathrm{Nd}$ & $\mathrm{Nd}$ \\
\hline Total acidity $\left(\mathrm{cmol} \mathrm{kg}^{-1}\right)$ & 1.38 & $\mathrm{Nd}$ & $\mathrm{Nd}$ & $\mathrm{Nd}$ \\
\hline $\begin{array}{l}\text { Exchangeable } \mathrm{K} \\
\left(\mathrm{cmol} \mathrm{kg}^{-1}\right)\end{array}$ & 0.24 & $0.05-0.19$ & 6.16 & 6.32 \\
\hline $\begin{array}{l}\text { Exchangeable Ca } \\
\left(\mathrm{cmol} \mathrm{kg}^{-1}\right)\end{array}$ & 0.76 & $0.05-0.19$ & 22.3 & 23.78 \\
\hline $\begin{array}{l}\text { Exchangeable Mg } \\
\left(\mathrm{cmol} \mathrm{kg}^{-1}\right)\end{array}$ & 0.45 & $0.07-0.21$ & 2.36 & 14.33 \\
\hline Texture & Sandy Loam & Sandy Loam & $\mathrm{Nd}$ & $\mathrm{Nd}$ \\
\hline
\end{tabular}

Note: *Subjected to the soil development, standard data range by Paramananthan (2000).

$\mathrm{Nd}=$ not determine.

\section{Conclusion and Recommendation}

The effect of $\mathrm{CZ}$ application with $75 \%$ fertilizers (E2) compared to $100 \%$ fertilizers (E1) were statistically similar for the selected soil chemical properties, dry matter production, nutrients concentration, nutrients uptake, and nutrients use efficiency except for N. Nitrogen use efficiency of E2 was better than that of E1. These findings suggest that adoption of $\mathrm{CZ}$ with $25 \%$ reduction of N, P, and $\mathrm{K}$ fertilizers are useful. Further field trials and economic analysis are recommended to confirm the findings of this study. These aspects are being investigated in our on-going field experiments.

\section{Acknowledgment}

The researchers acknowledge the support of this research by the Ministry of Higher Education Malaysia, through Universiti Putra Malaysia.

\section{References}

Ajirloo, G. S., Jadid, A. P., \& Nasirtabrizi, M. H. (2013). Effect of zeolite application on soil purification and some chemical properties of soil (case study), 970-974. 
Akande, M. O., Oluwatoyinbo, F. I., Kayode, C. O., \& Olowokere, F. A. (2008). Response of maize (Zea mays) and okra ( Abelmoschus esculentus ) intercrop relayed with cowpea (Vigna unguiculata) to different levels of cow dung amended phosphate rock. Journal of Biotechnology, 7(17), 3039-3043.

Allen, E., Ming, D., Hossner, L. R., Henninger, D., \& Galindo, C. (1995). Growth and nutrient uptake of wheat in clinoptilolite-phosphate rock substrates. Agron. J., 87, 1052-1059.

Allen, E. R., Hossner, L. R, Ming, D. W., \& Henninger, D. L. (1993). Solubility and cation exchange in phosphate rock and saturated clinoptilolite mixtures. Soil Science Society of America Journal, 57, $1368-1374$.

Barbarick, K., Lai, T., \& Eberl, D. (1990). Exchange fertilizer (phosphate rock plus ammonium-zeolite) effects on sorghum-sudangrass. Soil Sci. Soc. Am. J., 54, 911-916.

Brady, N. C., \& Weil, R. R. (2004). Elements of the Nature and Properties of Soils. Pearson Education, Inc., Upper Saddle River, NJ..

Bremner, J. M. (1965). Total Nitrogen. In C. A. Black, D. D. Evans, L. E. Ensminger, J. L. White, F. E. Clark \& R. D. Dinauer (Eds.), Methods of soil analysis, Part 2. (pp. 1149-1178). American Society of Agronomy. Madison, Wisconcin.

Cottenie, A. (1980). Soil testing and plant testing as a basis of fertilizer recommendation. FAO Soils Bulletin, 38, 70-73.

Daković A., Tomašević-Čanović M., Rottinghaus E.G., Matijašević S., \& Sekulić Ž. (2007). Fumonisin B1 adsorption to octadecyldimetylbenzyl ammonium modified clinoptilolite rich zeolitic tuff. Microporous and Mesoporous Materials, 105, 285-290.

Dobermann, A. R. (2005). Nitrogen Use Efficiency - State of the Art. Agronomy.Faculty Publications. Paper 316.

Eberl, D. D (1993). Controlled-Release Fertilizers Using Zeolites. U.S. Department of the lnterior U.S. Geological Survey, 93, 49-50.

Fontes, M. P. F., \& Weed, S. B. (1996). Phosphate adsorption by calys from Brazilian Oxisols: Relationships with specific surface area and mineralogy. Geoderma, 72, 37-51.

He, Z. L., Calvert, D. V., Alva, A. K., Li, Y. C., \& Banks, D. J. (2002). Clinoptilolite zeolite and cellulose amendments to reduce ammonia volatilization in a calcareous sandy soil. Plant Soil, 247, 253-260.

Kasim, S., Ahmed, O. H., Majid, N. M. A., Yusop, M. K., \& Jalloh, M. B. (2009). Effect of Organic Based N Fertilizer on Dry Matter (Zea mays L.), Ammonium and Nitrate Recovery in an Acid Soil of Sarawak, Malaysia. American Journal of Applied Sciences, 6, 1289-1294.

Keeney, D. R., \& Nelson, D. W. (1982). Nitrogen-Inorganic Forms. In D. R. Keeney, D. E. Baker, R. H. Miller, R. J. Ellis \& J. D. Rhoades (Eds.) Methods of Soil Analysis (Part 2, Vol. 9, pp. 159-165). American Society of Agronomy, Madison, WI., USA.

Kochian, L. V., Hoekenga, O. A., \& Pineros, M. A. (2004). How do crop plants tolerate acid soils?-Mechanisms of aluminum tolerance and phosphorous efficiency. Annual Review of Plant Biology, $55,459-493$.

Lai, T. M., \& Eberl, D. D. (1986). Controlled and renewable release of phosphorus in soils from mixtures of phosphate rock and NH4 exchanged clinoptilolite. Zeolites, 6, 129-132.

Malaysian Agricultural Research and Development Institute (MARDI). (1990). Jagung Manis Baru, Masmadu [New Sweet Corn, Masmadu]. (pp. 3-5). Institute of Malaysian Agricultural Research and Development Institute, Serdang, Malaysia.

Marschner, H. (1995). Mineral Nutrition of Higher Plants (2nd ed,), Academic Press, San Diego, CA., USA.

Ming, D. W., \& Allen, E. R. (2001). Use of natural zeolites in agronomy, horticulture, and environmental soil remediation. In D. L. Bish \& D. W. Ming (Eds.) Natural zeolites: occurrence, properties, applications. (pp. 619-654). Washington, DC.: The Mineralogical Society of America,

Ming, D. W., \& Dixon, J. B. (1986). Clinoptilolite in South Texas soils. Soil Sci. Soc. Am. J., 50, 1618-1622.

Murphy, J., \& Riley, J. I. (1962). A modified single solution method for the determination of phosphate in natural waters. Analytica Chimica Acta, 27, 31-36. 
Nnadi, L. A., \& Haque, I, (1998). Agronomic effectiveness of rock phosphate in an Andept of Ethiopia. Comm. Soil Sci. Plant Anal., 19, 79-90

Paramananthan, S. (2000). Soils of Malaysia: Their Characteristics and Identification (Vol. 1. pp. 11-125). Academy of Sciences Malaysia, Kuala Lumpur, Malaysia.

Peech, M. (1965). Hydrogen-ion Activity. In C. A. Black, D. D. Evans, J. L. White, L. E. Ensminger \& F. E. Clark (Eds.), Methods of Soil Analysis Chemical and Microbiological Properties (pp. 914-925). USA: American Society of Agronomy, Madison, WI.,

Petrus, A. C., Ahmed, O. H., Muhamad, A. M. N., Nasir, H. M., \& Jiwan, M. (2010). Effect of K-N-humates on dry matter production and nutrient use efficiency of maize in Sarawak, Malaysia. The Scientific World Journal, 10, 1282-92.

Piccolo, A. (1996). Humus and Soil Conservation. In A. Piccolo (Eds.). Humic Substances in Terrestrial Ecosystems, (pp. 225-264). Amsterdam: Elseiver.

Pickering, H. P., Menzies, N. W., \& Hunter, M. N. C. (2002). Zeolite/rock phosphate - a novel slow release phosphorus fertilizer for potted plant production. Scientia Horticulture, 94, 333-343.

Polat, E., Karaca, M., Demir, H., \& Naci-Onus, A. (2004). Use of natural zeolite (clinoptilolite) in agriculture. Journal of Fruit Ornamental Plant Research, 12, 183-189.

Rahmani, A. R., Mahvi, A. H., Mesdaghinia, A. R., \& Nasseri, S. (2004). Investigation of ammonia removal from polluted waters by clinoptilolite zeolite. International Journal of Environmental Science and Technology, 1, 125-133.

Ramesh, K., Biswas, A. K., Somasundaram, J., \& Subbarao, A. (2010). Nanoporous zeolites in farming: current status and issues ahead. Current Science, 99(6), 760-765.

Ramesh, K., \& Reddy, D. D. (2011). Zeolites and their Potential uses in Agriculture. In L. S. Donald (Ed.). Advances in Agronomy (Vol. 113, pp.219-241). Newark, USA: University of Delaware.

Rowell, D. L. (1994). Soil Science: Methods and Applications. (p. 169) London, UK: Longman Publishers Ltd.

Ruban, V., Sanchez, J. F., Rauret, G., Muntau, H., \& Quevauviller, P. (1999). Selection and evaluation of sequential extraction procedures for the determination of phosphorus forms in lake sediment. J Environ Monit $1,51-56$.

SAS. (2008). SAS/STAT Software. SAS Institute, Cary, NY.

Sims, J. T., \& Pierzynski, G. M. (2005). Chemistry of Phosphorus in Soils. In Chemical Processes in Soil, SSSA Book series 8, pp. (151-193) Madison, WI.

Tan, K. H. (2005). Soil sampling, preparation, and analysis (2nd ed). Boca Raton, Florida, USA.

Tarkalson, D. D., \& Ippolito, J. A. (2011). Clinoptilolite Zeolite Influence on Nitrogen in a Manure-Amended Sandy Agricultural Soil. Communications in Soil Science and Plant Analysis, 42(19), 2370-2378.

Zelazny, L. W., \& Calhoun, F. G. (1977). Palygorskite (attapulgite), sepiolite, talc, pyrophyllite, and clinoptilolite zeolite. In J. B. Dixon \& S. B. Weed (Eds.), Minerals in Soil Environments (pp. 435-470). SSSA, Madison, WI.

Zhang, T. Q., Mackenzie, A. F., Liang, B. C., \& Drury, C. F. (2004). Soil test phosphorus and phosphorus fraction with long-term phosphorus addition and depletion. Soil Science Society of America Journal, 68, 519-528.

Zhou, Q., \& Zhu, Y. (2003). Potential pollution and recommended critical levers of phosphorus in paddy soils of the southern Lake Tai area, China. Geoderma, 115, 45-54.

\section{Copyrights}

Copyright for this article is retained by the author(s), with first publication rights granted to the journal.

This is an open-access article distributed under the terms and conditions of the Creative Commons Attribution license (http://creativecommons.org/licenses/by/3.0/). 